研究

\title{
$\mathrm{Fe}$ 系メタル磁性粉の酸化安定性と構造
}

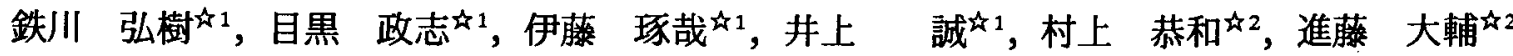 \\ ஷ・ソニー(侏)，テ985-0842 多賀城市桜木 3-4-1. \\ 到東北大学素材研究所, $\bar{T} 980-8577$ 仙台市青葉区片平 2-1-1.
}

\section{Oxidation Stability and Structure of Fe-Co Particles}

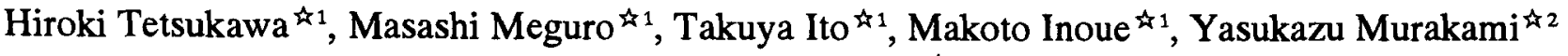 \\ and Daisuke Shindo th \\ ${ }^{4}$ sONY Corporation, 3-4-1 Sakuragi, Tagajo 985-0842. \\ 42 Institute for Advanced Materials Processing Tohoku University, 2-1-1 Katahira, Sendai 980-8577.
}

Received March 23, 2001

\begin{abstract}
SYNOPSIS
The oxidation stability and structure of acicular fine $\mathrm{Fe}-\mathrm{Co}$ particles have been investigated. The oxidation stability in the high temperature range is improved with the increase of Co content in the metal particles. It is observed that the shape of the cross section of Fe metal particles without $\mathrm{Co}$ is distorted and the surface oxide layer shows diffuse diffraction spots. On the contrary the shape of the cross section of Fe-Co particles is approximately circular and the surface oxide grows to be coherent with the core $\alpha$-Fe suggesting that the amount of the defects of the surface oxide layer reduces. Based on these results, it is found that the improvement of the oxidation stability by addition of $\mathrm{Co}$ is attributed to the morphology of the particles and the structure of the surface oxide layer around the core $\alpha-F e$. The oxidation stability also depends on the size of metal particles.
\end{abstract}

KEYWORDS

metal particle, oxidation stability, surface oxide layer, morphology

\section{1 緒 言}

Fe系メタル磁性粉は塗布型磁気記録媒体に広く用いられて おり，その開発においてCo添加により磁性粉ならびにテープ 特性は向上してきた ${ }^{1)}$.メ夕ル磁性粉のCo添加の効果は磁気 特性の向上の他に酎候性の改善,微粒子化などがあげられる1-乃. メタル磁性粉へのC添加により磁気テープの多数回走行時に みられる出力減衰は改善され, Co添加によりメタル磁性粉の 高温酸化安定性が向上することを報告しだ). また, 出力減衰 はヘッドとの摺動面におけるテープ表面のメタル磁性粉の酸 化による焼付きが原因であることから焼付きとメ夕ル磁性粉 の酸化安定性は関係していることが考えられるす。ししなか ら，焼付き発生はへッドとの摺動面におけるトライボケミカ ルな複雑な反応であり，不明な点が多い。また，Co添加した メ夕ル磁性粉の高温酸化反応恃末反応核モテル生成物層内拡 散律速であることから酸化反応は表面酸化物層か関係してい ることが考えられるが，その詳細な構造は明らかでない．

そこで, 本報告ではＣo 添加したメタル磁性粉の構造を調 べ, 酸化安定性について考察した。 また，焼付き発生が摺動
面における応力下での反応であるためメタル磁性粉の破壊強 度も調べた.さらに，高記録密度化に向けてメタル磁性粉は 微粒子化が進んでいるためメタル磁性粉のサイスの影響も調 ベた.

\section{2 実験方法}

サンプルは Co 量の異なるメタル磁性粉を用い，Co 量と磁 気特性を Table 1 に示した。構造解析はX 線回折, TEM 観察 (JEM-200CX), 高分解能 TEM観察(JEM-3000F)により行った. さらに高分解能TEM像をフーリエ変換し, 得られたパワース ペクトル像を解析した。表面分析はX 線光電子分光法 (XPS)

Table 1 Magnetic properties of metal particles.

\begin{tabular}{|c|c|c|c|}
\hline sample & $\mathrm{Co}[\mathrm{wt} \%]$ & $\sigma \mathrm{s}\left[\mathrm{Am}^{2} / \mathrm{kg}\right]$ & $\mathrm{Hc}[\mathrm{kA} / \mathrm{m}]$ \\
\hline A & 0 & 120 & 130 \\
\hline B & 16 & 150 & 150 \\
\hline C & 23 & 150 & 190 \\
\hline
\end{tabular}


を用い，エッチングにより深さ方向分析を行った．破壊強度 はメタル磁性粉を $3 \mathrm{~mm} \phi$ スチールボールにより一定時間ミリ ングした後に磁気特性 $\left(\mathrm{Hc}, \sigma_{\mathrm{s}}\right)$ を測定した。

热分析は TG-DTA 法を用いて， $\mathrm{N}_{2}$ 雾囲気中で $473 \mathrm{~K}$ まで昇 温した後， $80 \% \mathrm{~N}_{2}+20 \% \mathrm{O}_{2}$ 混合ガス雾囲気中で $30 \mathrm{~min}$ 保持し たときの TG曲線を調へたた. TG曲線を酸化反応終了時の重量 增加により規格化を行い，酸化反応率とした。すなわち，酸 化反応終了後では酸化反応率は 1 となる.

また，メタル磁性粉を $80 \% \mathrm{~N}_{2}+20 \% \mathrm{O}_{2}$ 混合ガス雾囲気中に て $573 \mathrm{~K}$ に昇温・保持し，酸化反応が終了したとき(TG 曲線 が飽和したとき)に得られた生成酸化物の構造解析も行った.

\section{3 結果およひ考察}

3.1 Co 添加したメタル磁性粉の構造

Co添加によるメタル磁性粉と酸化反応後の生成物の構造を 調ベるために X線回折を行い，サンプル $\mathrm{A}(\mathrm{Co}=0 \mathrm{wt} \%$ \%) とサ ンプル B(Co=16wt.\%) の結果を Fig.1 に示す. Co 添加に関わ らず, コア部の $\alpha-\mathrm{Fe}$ の格子定数は約 $2.865 \AA$ であり，ほほ一 定であった. Fig.1 からサンプルAでは表面酸化物層である $\mathrm{Fe}_{3} \mathrm{O}_{4}, \gamma-\mathrm{Fe}_{2} \mathrm{O}_{3}$ がみられた. 一方, Co添加したメ夕ル磁性粉サ ンプルBの表面酸化物層のピークはほとんどみられなかった。

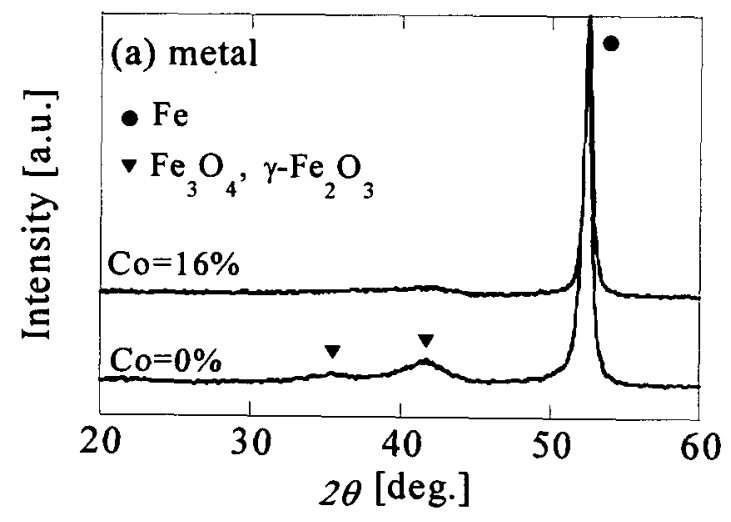

(a)

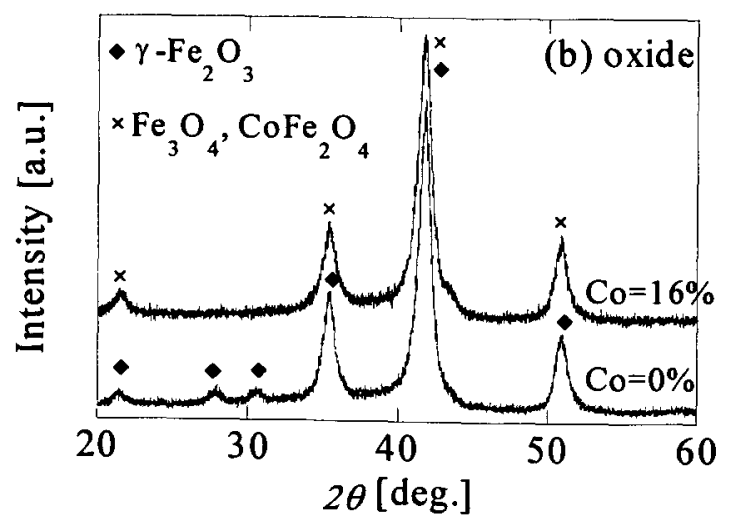

(b)

Fig.1 $\mathrm{X}$-ray diffraction patterns for $\mathrm{A}(\mathrm{Co}=0 \%)$ and $\mathrm{B}(\mathrm{Co}=16 \%)$, and (a) before (metal) and (b) after oxidation (oxide).
次に，573K での酸化反応後の生成物からサンプル A は $\alpha-\mathrm{Fe}$ から $\mathrm{Fe}_{3} \mathrm{O}_{4}$ ，さらに $\gamma-\mathrm{Fe}_{2} \mathrm{O}_{3}$ へ酸化していることが分かった。一 方, $\mathrm{Co}$ 添加したサンプル B の生成酸化物は $\mathrm{Fe}_{3} \mathrm{O}_{4}, \mathrm{CoFe}_{2} \mathrm{O}_{4}$ で あり, $\gamma-\mathrm{Fe}_{2} \mathrm{O}_{3}$ はなかった. 生成酸化物である $\mathrm{Fe}_{3} \mathrm{O}_{4}, \mathrm{CoFe}_{2} \mathrm{O}_{4}$ $\gamma-\mathrm{Fe}_{2} \mathrm{O}_{3}$ の結晶構造や格子定数はほぼ等しいことが知られてい るの. 以上の結果加ら Co 添加による酸化安定性向上はメタル 磁性粉や生成酸化物の結晶構造や格子定数の差によるもので はないことが分かった。

メタル磁性粉の表面状態を調へるためにXPS 測定を行い， Fe2pのXPSスペクトルを Fig.2(a),(b)に示す. エッチンクによ り深さ方向への分析を行った. Fig.2(a)においてBinding Enegy が711eVおよび710 eVのピークはそれそれ $\mathrm{Fe}^{3+}, \mathrm{Fe}^{2+}$ に対応し ており，サンプル Aの表面は $\mathrm{Fe}_{3} \mathrm{O}_{4}, \gamma-\mathrm{Fe}_{2} \mathrm{O}_{3}$ であり，エッチン グするとコア部である $\alpha-\mathrm{Fe}$ (Binding Enegy=707eV)が現れた. 一方, Fig.2(b)からサンプル $\mathrm{C}(\mathrm{Co}=23 \mathrm{wt} . \%)$ では表面に $\mathrm{Fe}^{3+}$ か 多く存在しており，Fig.1の結果とあわせ考えると表面酸化物 層は $\mathrm{CoFe}_{2} \mathrm{O}_{4}, \mathrm{Fe}_{3} \mathrm{O}_{4}$ であることが分かった.サンプルCはサン プルAより少ないエッチングでコア部の $\alpha$-Feが現れることか ら Co 添加したメタル磁性粉の表面酸化物層は薄いことが分 かった.これから表面酸化物層の厚みが酸化安定性向上の原 因ではないことが分かった。

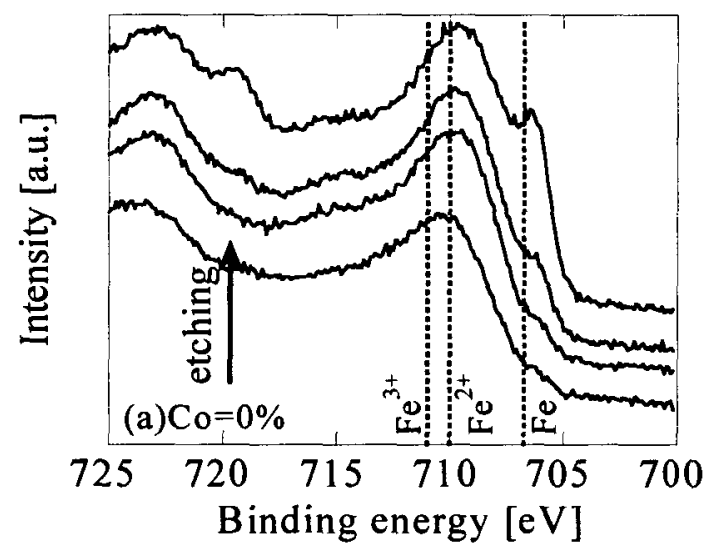

(a)

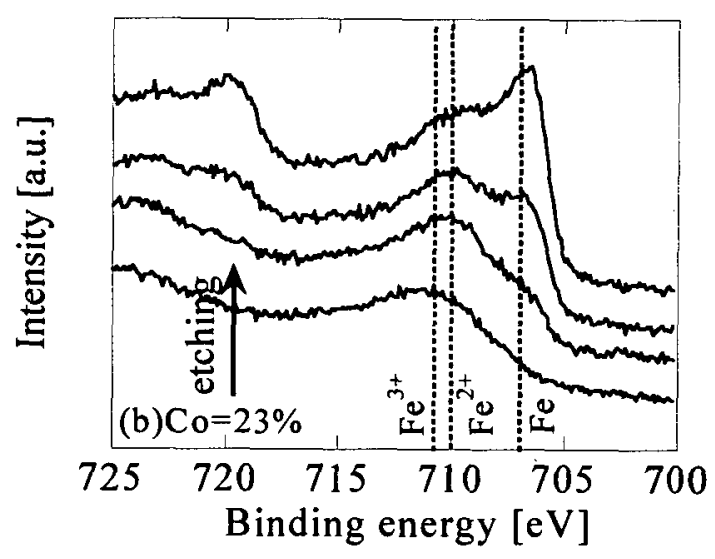

(b)

Fig.2 XPS spectra of Fe2p in (a) $\mathrm{A}(\mathrm{Co}=0 \%)$ and (b) $\mathrm{C}(\mathrm{Co}=23 \%)$. 
さらに, 詳しくメタル磁性粉の構造を調べるために高分解 能 TEM (High Resolution TEM) 観察を行った. サンプル A(Co $=0 \mathrm{wt} . \%)$ ならびにサンプル C $(\mathrm{Co}=23 \mathrm{wt} . \%)$ のメタル磁性粉断 面の高分解能TEM像とそれをフーリエ変換したパワースペク トル像を Fig.3,4にそれぞれ示す. メ夕ル磁性粉断面はテープ を配向方向に対して垂直に切断し, 観察した. Fig.3(a)からサ ンプル Aの断面は歪んでおり, 表面酸化物層の表面に凹凸が みられた. Fig.3(a)のパワースペクトル像である Fig.3(b)にお いて丸印で示したように酸化物の回折スポットがシャープで ないことから酸化物の格子は歪んでいることが考えられる. すなわち, サンプル Aの表面酸化物層は転位, 格子欠陥が多 く含んでいると考えられる.一方, Fig.4(a)から分かるように サンプルCの断面は円形状であった. Fig.4(b)でのパワースペク トル像から酸化物の回折スポットはシャープであり, Fig.4(a) において $\alpha$-Feの格子縞はほほ磁性粉表面まで達していること からコア部の $\alpha-\mathrm{Fe}$ と表面酸化物層の整合性はよく, 転位, 格 子欠陥が少ないことが分かった. 以上の結果からCo添加によ りメタル磁性粉の断面は歪んだ形状から円形状になり, 表面 酸化物層は転位, 格子欠陥を多く含んだ構造から欠陥の少な い整合性のよい構造になり, 緻密になることが分かった.

次に, 焼付き発生がトライボケミカルな反応であることか らメタル磁性粉の破壊強度と酸化について調べた. スチール ボールにより一定時間ミリングを行い, 衝撃を与えた後のメ タル磁性粉の Hc と $\sigma_{\mathrm{s}}$ を測定した結果を Fig.5に示す. Fig.5 か らサンプル AのHcはサンプルBより減少率が大きいことから

\section{(a)}

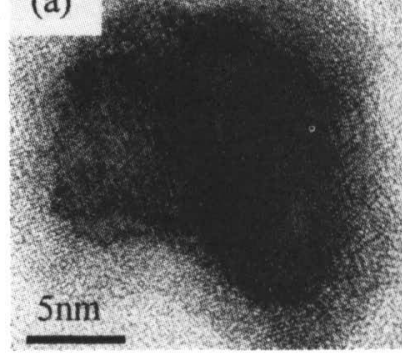

(b)

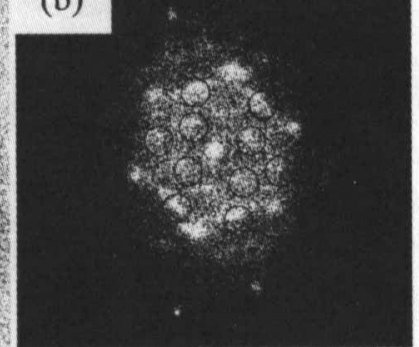

Fig.3 (a) HRTEM image of A and (b) Fourier power spectrum of image (a).

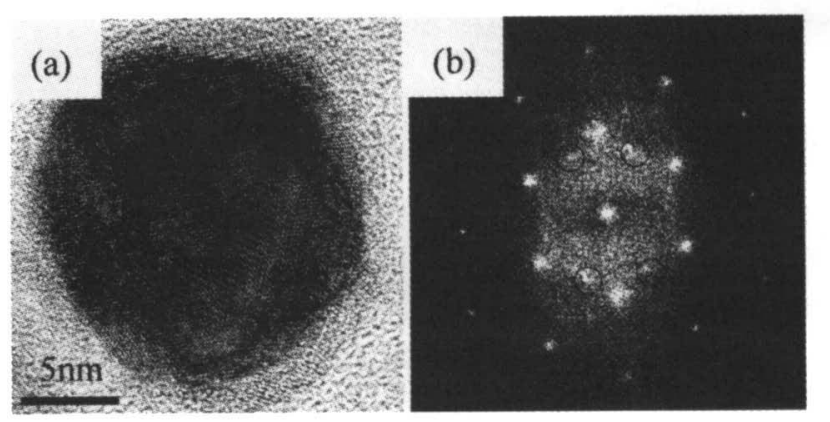

Fig.4 (a) HRTEM image of $\mathrm{C}$ and (b) Fourier power spectrum of image (a).
メ夕ル磁性粉の形状は変化し，壊れやすいことが分かった. また, $\sigma_{\mathrm{s}}$ の減少からメタル磁性粉の破壊にともない酸化反応 が進行していた.これからCo添加はメタル磁性粉の破壊強度 にも効果があることが分かった. 高分解能TEMの結果と合わ せて考えるとサンプルAの表面酸化物層はより多結晶であり, 欠陷を多く含んでいるためメ夕ル磁性粉は壊れやすい.一方, サンプルBはCo添加により表面酸化物層の結晶性が絰密にな るためメ夕ル磁性粉の破壊強度は向上すると考えられる.

\section{2 メ夕ル磁性粉のサイズの効果}

高記録密度化にともないメ夕ル磁性粉の微粒子化が進んで いる. そこで, メタル磁性粉のサイスと高温酸化安定性の関 係を調べ，Co 量と合わせて Fig.6にまとめた. メ夕ル磁性粉 の針状比は約 6である. 破線は酸化反応率を表わしており， Co量と長軸長サイスの異なるメ夕ル磁性粉の酸化反応率から 内挿して求めた. メ夕ル磁性粉の高温酸化安定性はCo添加に より向上し, 微粒子化にともない劣化した. 微粒子化による 劣化の原因としてメタル磁性粉の比表面積が大きくなるため 反応界面積が多くなり, 酸化されやすいことが予想される.

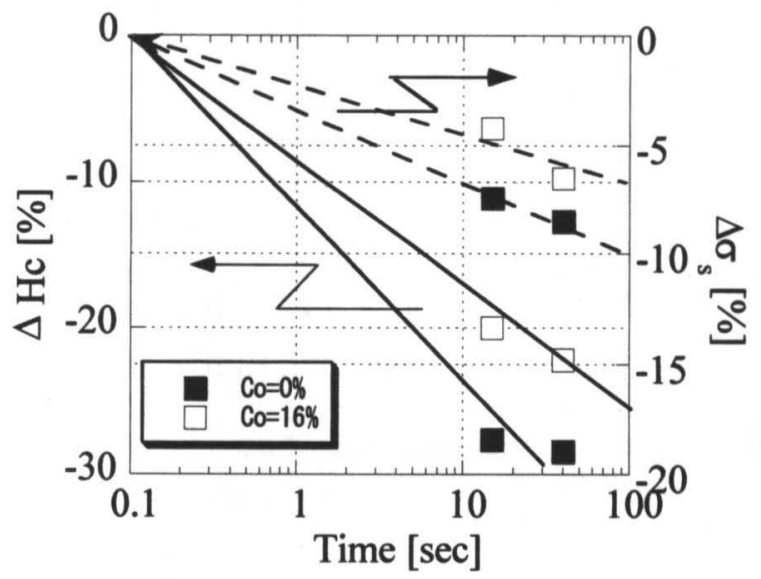

Fig.5 Decrease in $\mathrm{Hc}$ (solid line) and $\sigma_{\mathrm{s}}$ (dashed line) of (a): $\mathrm{A}$ (Co $=0 \%)$ and $(\mathrm{b}): \mathrm{B}(\mathrm{Co}=16 \%)$ vs milling time.

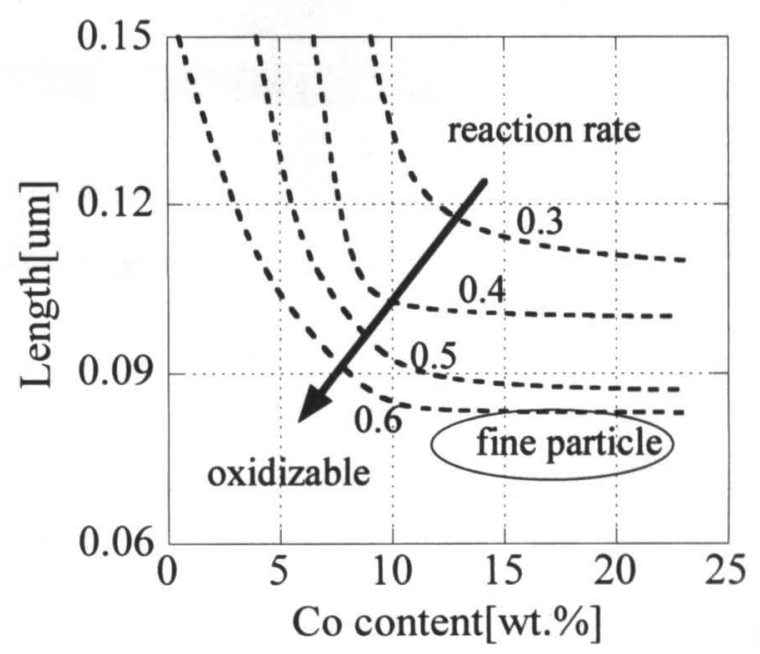

Fig.6 Dependence of oxidation stability on Co content and length of metal particles. 
そこで, Co=9\%のメタル磁性粉において比表面積で規格化し た高温酸化安定性とサイスの関係を Fig.7に示す.微粒子化に ともない酸化反応率/比表面積は大きくなった. さらに, 酸化 反応機構の解析からサイスが小さくなるに従い, 未反応核モ テルの生成物層内拡散律速から外れた. これらの結果から酸 化安定性は酸化反応の反応界面積の大きさのみによって依存 しているのではないことが分かった.

そこで, 微粒子メタル磁性粉 (長軸長 $=0.07 \mu \mathrm{m}$ ) 断面の TEM 観察の結果を Fig.8に示す. Fig.3(a)にみられるTEM像ほど顕 著ではないか，微粒子の断面は歪んでいることが分かった.

以上のことからメタル磁性粉のコアである $\alpha$ - Feのサイスお よび形状に深く関係すると考えられる $\alpha$ - Feの還元工程につい て検討した. 還元温度を高くすることにより, 充分に $\alpha$ - Feを

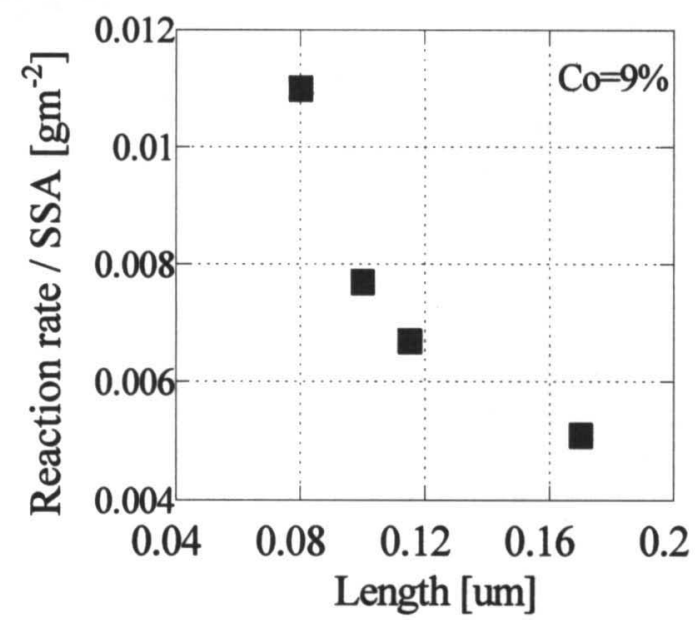

Fig.7 Relation between reaction rate by specific surface area and particle length.

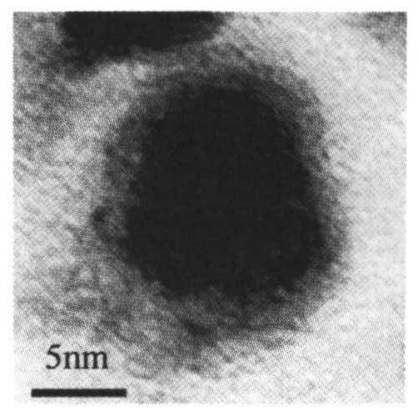

Fig.8 TEM image of fine metal particle $(\mathrm{L}=0.07 \mu \mathrm{m})$.

Table 2 Effect of reduction process of metal particles on oxidation stability. (a) reference, (b) reduce-treated at high temperature.

\begin{tabular}{|c|c|c|c|}
\hline & Dx[nm] & SSA $\left[\mathrm{m}^{2} / \mathrm{g}\right]$ & Reaction rate \\
\hline (a) & 19 & 49 & 0.62 \\
\hline (b) & 22 & 46 & 0.50 \\
\hline
\end{tabular}

核生成, 成長させたメタル磁性粉の高温酸化安定性を調ベ, Table 2にまとめた. Table 2から還元温度を高くすることによ りメタル磁性粉の酸化反応率は大きく改善され, 高温酸化安 定性が向上することが分かった．これは還元温度を高くする ことにより $\alpha$-Feは充分成長し, 緻密な表面酸化物層が形成さ れるためであると考えられる.

以上の結果からメタル磁性粉の酸化安定性の原因について 考察する. メ夕ル磁性粉の酸化安定性は表面酸化物層に起因 している.Co添加によりメタル磁性粉は断面が歪んだ形状か ら円状になり, 表面酸化物層は転位, 格子欠陥の減少から絰 密になり, 酸化安定性は向上する.メ夕ル磁性粉は還元した $\alpha-\mathrm{Fe}$ を徐酸化工程により表面酸化物層を形成し，作製され る.これから表面酸化物層の緻密性は還元後の $\boldsymbol{\alpha}$ - $\mathrm{Fe}$ の形状に 関係していると考えられる. Table 2に示したように還元温度 を高くすることにより酸化安定性が向上することからも表面 酸化物層の緻密性は $\alpha$ - $\mathrm{Fe}$ の還元反応と関係している. そこ で, 還元反応について熱力学的に考察を行う. 酸化・還元反 応の標準自由エネルギー変化から Co は Feより還元されやす いわ. そのためCo添加により $\mathrm{Fe}$ の還元反応は促進されること が定性的に分かる.これからCo添加により還元反応が促進さ れるため $\alpha-\mathrm{Fe}$ は充分成長し, 断面は円形状になり, 徐酸化工 程での表面酸化物層は整合的に形成され，緻密になることが 考えられる. さらに，このような表面酸化物層は転位，格子 欠陥が少ないため機械的強度にも優れており,ヘッドとの摺 動面においてもメタル磁性粉の破壊および活性界面の出現か 起こりにくいためメタル磁性粉の酸化ならびに出力減衰を抑 制することが分かった.

次に，微粒子メ夕ル磁性粉について考察する，微粒子化に よる酸化安定性の劣化は比表面積すなわち酸化反応の反応界 面積の大きさにのみ依存しているのではない. 酸化安定性か $\alpha-\mathrm{Fe}$ の還元温度に関係していることから次のことが考えられ る. 微粒子メタル磁性粉はサイスを制御するために還元反応 での $\alpha-\mathrm{Fe}$ の成長を抑制しなければならず，歪んだ形状にな り, 表面酸化物層は整合的に成長することが出来ず，佰の 多い構造になる.そのため酸化安定性が劣化すると推察でき る. 今後は次世代微粒子メ夕ル粉の酸化安定性の向上が課題 となる.さらに，焼付きの分析とあわせ，メ夕ル磁性粉の高 温酸化反応との定量的な関係を調へ，焼付き発生機構の解明 とその抑制について検討の必要がある.

\section{4 ま と め}

Co添加によるメ夕ル磁性粉の高温酸化安定性の向上は表面 酸化物層の緻密性に起因していることが分かった.Co添加し ないメ夕ル磁性粉の断面形状は歪んでおり, 表面酸化物層は 転位, 格子欠陥を含む. Co添加によりメタル磁性粉の断面形 状は円形になり, 表面酸化物層は整合的に成長し, 繳密にな ることが分かった.これによりメタル磁性粉の破壊強度も向 上する. また, 酸化安定性はメタル磁性粉のサイスにも依存 している. 
文献

1) K.Okamoto et al.: "Advanced metal particles'•", J. Mag. Mag. Mater., 155(1996)60-66.

2) M.Kishimoto et al.: "Preparation and magnetic properties...", IEEE Trans. Magn., 27(1991)4645-4647.

3) 正木幸一ら: "極薄磁性層を有する淕布型磁気記録媒体用 メタル微粒子...", 粉体および粉末治金, 43(1996)961-965.
4) 鉄川弘樹ら: "Co添加した Fe系メタル微粒子...”, 粉体およ び粉末治金, 47(2000)748-751.

5) B.Bhushan et al.: "Stains on magnetic tape heads", Wear, 184 (1995)193-202.

6)磁性体ハンドブック,朝倉書店,(1975)612.

7) 冶金物理化学, 日本金属学会, (1982)73. 